\title{
VPLIV LOKALNIH VIROV EMISIJ IN ČEZMEJNEGA PRENAŠANJA ONESNAŽENEGA ZRAKA NA KAKOVOST OKOLJA V ALPSKEM EKOSISTEMU SLOVENIJE
}

\begin{abstract}
Metka Špes*
Izvleček

$U D K 504.3 .054(497.4)$

Prispevek opozarja na onesnaženost ozračja v alpskem ekosistemu Slovenije, ki je na eni strani posledica razmeroma šibkega lokalnega onesnaževanja $v$ dolinah in kotlinah z nizkimi samočistilnimi sposobnostmi, na drugi strani pa tudi čezmejnega prenašanja emisij.

Ključne besede: alpski ekosistem, onesnaževanje zraka, majhne samočistilne sposobnosti zraka $v$ alpskih kotlinah in dolinah, čezmejno prenašanje emisij, žveplovi in dušiki depoziti, kislosti padavin.

THE IMPACT OF LOCAL EMISSION SOURCES AND TRANSBORDER TRANSMISSION OF POLLUTED AIR ON THE ENVIRONMENTAL QUALITY OF THE ALPINE ECOSYSTEM IN SLOVENIA

Abstract:The paper emphasizes that the air pollution in Alpin ecosystem in Slovenia is influenced by poor neutrlizing and self- purifying air capacitis in Alpine valleys and basins whith the relatively small quantitis of harmful emissions. The quality of air is also influenced by transborder transmission of emissions.
\end{abstract}

Key words: alpine ecosystem, air pollution, poor self-purifying capacities of the air in alpine valleys and basins, transborder transmission of polluted air, sulphor and nitrogen deposits, acidity of percipitation.

\footnotetext{
* Dr. univ. doc., Oddelek za geografijo, Filozofska fakulteta Univerze v Ljubljani, Aškerčeva cesta 2, 1000 Ljubljana, Slovenija
} 


\section{UVOD}

Med osnovna načela trajnostnega razvoja, ki jih je leta 1987 zapisala Svetovna komisija za okolje in razvoj (WCED, bolj poznana kot Brundtlandova komisija, vodila jo je namreč nekdanja norveška predsednica vlade), kasneje pa s podpisom Agende 21 sprejela še večina svetovnih voditeljev na konferenci v Riu de Janeiru, spada tudi zahteva po izboljševanju kakovosti življenja in razvoju, ki bo upošteval naravne regeneracijske sposobnosti oziroma nosilne zmogljivosti okolja. Če se omejimo le na en naravni vir, zrak, bi omenjeni dve načeli lahko preprosto združili v zahtevo po zmanjšani "proizvodnji” emisij, ki izvirajo predvsem iz uporabe fosilnih goriv, in načrtovanju nadaljnjega razvoja, ki bo upošteval omejene samočistilne sposobnosti zraka. S tem se bodo zmanjšali tudi posredni in neposredni negativni učinki na naravne sestavine okolja, zagotovljeno pa bo kakovostnejše in bolj zdravo življenje.

Pri onesnaženosti ozračja v Alpah velja na eni strani poudariti, da imajo alpski ekosistemi zaradi reliefne razgibanosti in $\mathrm{z}$ njo povezanimi specifičnimi meteorološkimi pojavi razmeroma slabo samočistilno sposobnost zraka. Najizraziteje se to kaže $\mathrm{v}$ alpskih in predalpskih dolinah ter kotlinah, kjer močne negativne pokrajinske učinke povzročijo že razmeroma majhne količine škodljivih emisij, čeprav ne gre zanemariti tudi dejstva, da prevladujoče karbonatne kamenine razmeroma uspešno nevtralizirajo učinke kislega dežja. Druga okoljevarstvena značilnost je tudi sama lega Alp. So namreč sredi največjih virov emisij (predvsem energetskih in industrijskih) v zahodni in srednji Evropi. S širjenjem emisij v zgornjih zračnih plasteh (vpliv visokih dimnikov!), tudi čez državne meje, se zato pojavljajo povišane imisije tudi v okolju, kjer ni večjih avtohtonih virov emisij. Posledice so vidne predvsem na poškodovani vegetaciji, zakisanju gorskih jezer itd. Za preprečitev nadaljnjega ogrožanja Alp je šest srednjeevropskih držav leta 1991 podpisalo Alpsko konvencijo, naslednjega leta pa se jim je pridružila še Slovenija. Podpisnice so se zavezale medsebojnemu sodelovanju pri reševanju ekoloških vprašanj. Med pomembnimi cilji pri varovanju alpskega okolja je tudi varstvo zraka, ki naj bi se zagotavljalo z odločnim zmanjševanjem škodljivih emisij tako na območju Alp kot tudi drugod (Premzl, 1994). 


\section{POKRAJINSKI UČINKI ONESNAŽEVANJA OZRAČJA V ALPSKIH DOLINAH IN KOTLINAH NA PRIMERU MEŽIŠKEGA IN ZGORNJESAVSKEGA IMISIJSKEGA OBMOČJA}

V preteklih desetletjih, ko je bila onenaženost ozračja v Sloveniji največja, sta se med najbolj degradirane slovenske pokrajine uvrščali tudi dve alpski dolini: Zgornjesavska in Mežiška. Glavni industrijski viri in manjša naselja so sicer prispevali razmeroma majhne količine škodljivih emisij, vendar je bila njihova lega $\mathrm{v}$ ozkih in globokih dolinah z omejenimi samočistilnimi sposobnostmi z ekološkega vidika najmanj ugodna, saj se je pokazalo veliko neorazmerje med emisijami in imisijami.

Pri negativnih pokrajinskih učinkih lokalnih virov onesnaževnja opažamo, da so najbolj degradirane alpske pokrajine omejene na ozke in globoke gorske doline. Imisijska območja so sicer izrazita, vendar lokalna, med seboj ločena z vmesnim vzpetim svetom (gorski, hriboviti), ki ni imel stalnega povečanega onesnaževanja in je razmeroma čist. Njihova lega na dnu globokih dolin stopnjuje tudi stisko s prostorom, zato se industrijske, komunalne in druge funkcije mestnega prostora med seboj močno prepletajo.

Mežiška dolina ima izrazito zaprto, zatišno lego, ki pa ni le posledica globoke gorske doline, temveč prav tako tudi njene lege na obrobju Celovške kotline, kar posredno stopnjuje pogostnost temperaturnih inverzij in s tem tudi onesnaženost ozračja (skica 1). Zgornji del Mežiške doline je ekološko zelo občutljiva pokrajina, kjer prevladujejo strmine oziroma pobočja, ki jih pred erozijo tal varuje le gozdna odeja. Poleg trših in odpornejših karbonatnih tal so tudi mehkejša in nepropustna silikatna tla, ki kisline iz onesnaženega zraka in padavin teže nevtralizirajo. Ta del doline je povečini zelo ozek, globok, skratka zelo zaprt, pesti ga še prostorska stiska, največji onesnaževalci zraka pa so ravno v najbolj zaprtem delu doline.

V metalurško usmerjeni Mežiški dolini so bili žveplovi oksidi najpomembnejše emisije, čeprav sta v preteklosti (pred ekološko sanacijo in vgradnjo filtrov) kvarila ozračje in okolje sploh tudi svinec iz topilnice in rdeči železarniški prah. Če seštejemo vse te emisije (pred sanacijami ali po njih) v celotni Mežiški dolini, vidimo, da gre pravzaprav za manjše količine, ki pa v zaprti, slabo prevetreni in ekološko občutljivi pokrajini vseeno prizadenejo okolje. Svoj delež pri onesnaževanju zraka prispevajo tudi gospodinjstva $\mathrm{z}$ ogrevanjem stanovanj. Te emisije so toliko bolj škodljive, ker nastajajo $\mathrm{v}$ zimskih mesecih, ob najbolj neugodnih meteoroloških razmerah.

S prvim razvrščanjem slovenskih krajev v posamezne razrede onesnaženosti ozračja leta 1975 so se vsa štiri urbana naselja Mežiške doline (Črna, Žerjav, Mežica, Ravne) znašla v 4. razredu, torej ne le s čezmerno, temveč celo kritično onesnaženim zrakom. Po sanaciji ravenske železarne ter zgraditvi toplovoda ter prašnih filtrov v žerjavski 
topilnici svinca je naslednja kategorizacija leta 1988 med kritično onesnažene kraje (IV. razred) uvrstila le še Črno in Mežico, Žerjav pa v čezmerno onesnažene.

Skica 1:Prečni prerez doline Meže pri Žerjavu

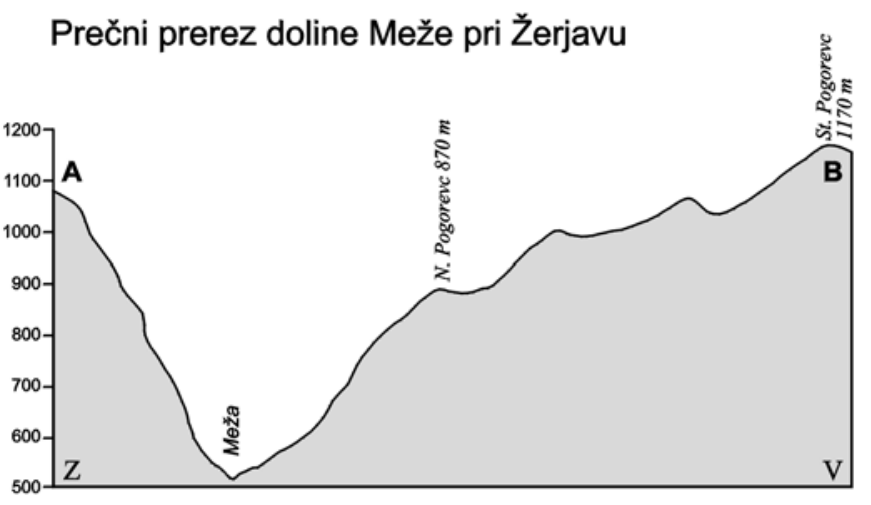

V okolici Črne, Žerjava in Mežice so že leta 1961 ocenili, da je gozd poškodovan na površini skoraj 1500 ha, od tega pa je skoraj deset odstotkov povsem uničenega. Ob preučevanju dve leti kasneje so se te površine povečale že na 2360 ha, leta 1966 pa je bilo samo v okolici Žerjava več kot 2000 ha poškodovanih gozdov (Šolar, 1972). Sredi 70. let so se poškodbe na gozdovih še širile, bilo jih je že 2700 ha, od tega že 280 ha goličav, ki so strnjene v glavnem okoli Žerjava (Dolina smrti). Prav v tem času je prihajalo do najmočnejših ožigov, gozdno drevje ni propadalo le znotraj opredeljenega imisijskega območja, temveč se je širilo tako, da je bilo ob koncu desetletja že več kot 3200 ha poškodovanih gozdov (Šolar, 1978). Z novejšimi raziskavami, ki se metodološko razlikujejo od prejšnjih, so registrirali popisne točke z več kot $90 \%$ poškodovanih gozdov na jugozahodnem obrobju Zgornje Mežiške doline, na pobočjih Olševe in Smrekovškega pogorja in tudi v okolici Mežice pa vse do avstrijske meje. V Spodnji Mežiški dolini so opazovalne točke s tako močno poškodovanimi gozdovi našli še zahodno od Raven. Tod segajo vse do avstrijske meje gozdovi s 70\% poškodovanega drevja (Inštitut za gozdno in lesno gospodarstvo, 1992).

Za hribovski del Pomežja je značilna poselitev v obliki samotnih kmetij. Te so bile v preteklosti (deloma so še sedaj) eksistenčno vezane na gozd. Svoj obstoj so v glavnem opirale na gozdnato pokrajino, manj pa na živinorejo ali poljedelstvo. Poleg tega je hitro propadanje gozda, ki je imel na strmih pobočjih s plitvo prstjo izrazito varovalno funkcijo, sprožilo zelo hudo degradacijo okolja, ki bi se tudi pri takojšnjem prenehanju onesnaževanja težko popravilo. 
Do leta 1978, ko so v topilnici vgradili filtre in so se zmanjšale imisije svinca in drugih kovinskih delcev, so pogosto ugotavljali močno povišane koncentracije svinca $\mathrm{v}$ listnati zelenjavi in gomoljnicah (v korenju je bilo do $39 \mathrm{mg} / \mathrm{kg}$ svinca, drugod $\mathrm{v}$ Sloveniji pa v povprečju $0,29 \mathrm{mg} / \mathrm{kg}$; Kerin, 1978), v senu ter vzporedno s tem še v krvi, jetrih in ledvicah živine (Gregorovič, 1984). Povišane koncentracije svinca v krvi so se pokazale tudi pri nekaterih analizah krvi prebivalcev Zgornje Mežiške doline (Sušnik, 1978).

Zgornjesavsko imisijsko območje je značilna alpska gorata pokrajina s hitrimi reliefnimi spremembami na manjših razdaljah. To pa pomeni, da se hitro spreminja tudi njena občutljivost na antropogene posege. Najpomembnejša pokrajinska elementa sta relief (strmina, ekspozicija, nadmorska višina), ki vpliva tudi na meteorološke pojave, in litološka zgradba). Dolina, ki je tudi vezni člen med Julijskimi Alpami in Karavankami, čeprav je tektonsko zasnovana in ledeniško preoblikovana, ni posebej široka. Najožja je prav pri Jesenicah (skica 2). Za razliko od Mežiške doline pa ima bolj značilne dolinske meteorološke razmere z razmeroma dobro prevetrenostjo. V ozki dolini se pojavljajo vzhodne, predvsem pa zahodne smeri vetrov, torej vzporedno $\mathrm{z}$ osjo doline. Za širjenje onesnaženega zraka so pomembni še lokalni vetrovi, za Jesenice so namreč značilni pobočni vetrovi. Ponoči se hladnejši zrak spušča po pobočjih proti dolini, podnevi pa se, predvsem po prisojnih ogretih pobočjih, dviga. Ob močnejših vetrovih se v višjih zračnih plasteh veter v dolini kanalizira. Smer ni odvisna od dnevnega časa in temperaturnih razlik med dnom doline in pobočji. Prevetrenost doline praviloma onemogoča tudi nastajanje temperaturne inverzije in zgoščevanje emisij. Posredni kazalec inverzije je nastajanje megle, čeprav ta dva pojava nista vedno povezana. V 20-letnem povprečju (1950-70) so imele Jesenice le do 10 meglenih dni na leto, v sosednji Radovljiški kotlini je megla že pogostejša, $v$ Lescah pa je bilo v omenjenem obdobju povprečno že 61 meglenih dni na leto.

Tudi pri onesnaževanju jeseniškega dela Zgornjesavske doline sta nekdaj prevladovala SO2 in železarniški prah. Slednji je dolga desetletja dajal pečat zaprašenemu mestu (predvsem z rdečim železarskim prahom). Glavni vir emisij prahu so bile Siemens-Martinove peči, kjer je čiščenje oziroma lovljenje prašnih emisij tudi tehnično skoraj nemogoče. Največje količine prašnih emisij so Jesenice poznale do leta 1970, to je bil tudi čas, ko so se "rdeče pobarvala" pročelja hiš v okolici železarne. Pri proizvodnji ene tone jekla je bilo kar 6-11 kg prašnih emisij, v katerih so prevladovali železovi oksidi.

Pri zimskem onesnaževanju Jesenic prispevajo svoj delež še gospodinjstva, ki v gospodarsko depresivnem kraju z velikim deležem nižjih socialnih skupin prebivalstva uporabljajo cenena kuriva s slabšo kalorično močjo in večjo vsebnostjo žvepla. Poleg tega alpske podnebne razmere $s$ hladnejšimi in daljšimi zimami povečajo intenzivnost ogrevanja in ga tudi podaljšujejo. 
Skica 2:Prečni prerez Zgornjesavske doline.

\section{Prečni prerez Jeseniške doline}

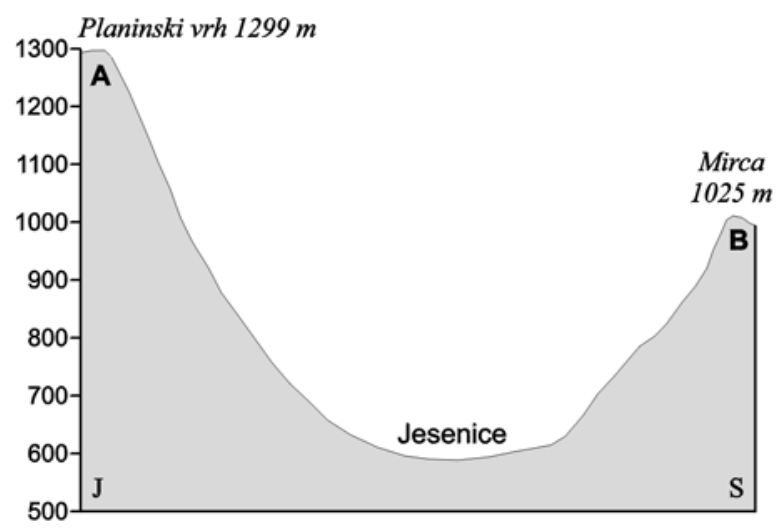

Po občasnih meritvah imisij $\mathrm{SO}_{2}$ v letih 1965 in 1971/72 so se Jesenice že sredi 70.

let uvrščale med čezkomerno onesnažene kraje. Ko je ob koncu 60. let vseh šest Siemens-Martinovih peči $\mathrm{v}$ železarni polno obratovalo, je Jesenice pestilo močno onesnaževanje ozračja $\mathrm{z}$ rdečim železarniškim prahom. Po podatkih Zavoda za zdravstveno varstvo (1966) je bila takrat povprečna zaprašenost kar 14-krat večja od higienskih normativov. Meritve zadnjih let pa kažejo, da so prašne usedline v povprečju pod MDK(maksimalne dovoljene koncentracije) tudi po strožjih normativih za stanovanjsko okolje.

Za razliko od Mežiške doline je jeseniško imisijsko območje manj degradirano. Na eni strani je bilo to ves čas izrazito železarsko območje s prevladujočimi prašnimi emisijami, ki so težje in se ne raznašajo na večje razdalje. Na drugi strani pa so opazni pozitivni učinki dobre prevetrenosti ozke doline, pretežno karbonatna sestav kamenin pa poleg vsega še dobro nevtralizira kisle padavine. Do začetka 70. let, ko je bilo onesnaževanje ozračja najhujše, je bilo $\mathrm{v}$ okolici Jesenic 30 ha zelo poškodovanih gozdov, imisijsko območje z bolj ali manj prizadetim drevjem pa je bilo seveda obsežnejše. Najbolj je bila prizadeta okolica javorniških obratov železarne, kjer iglavci niso več uspevali, razraščati sta se začela slab, redek brezov gozd in grmičevje (Maček, 1972). V smeri najpogostejših vetrov, na Dobravskem polju, Bregu in na pobočjih Homa in Mežakle, pa so bile najdebelejše prašne usedline. Tako je bilo sredi 70. let skupaj prizadetih skoraj 1900 ha gozdov, le da med njimi skoraj ni bilo goličav ali zelo poškodovanih gozdov. Po letu 1978 so znake poškodb opazili le še v najožji okolici železarne. 
Med pomembnejše aktualne lokalne vire emisij v slovenskih alpskih pokrajinah gre šteti tudi promet. Prometno najbolj obremenjeni cestni odseki v slovenskih Alpah so pri Jesenicah, kjer so v letu 1997 našteli povprečno 11042 motornih vozil na dan, pri Kranjski gori za polovico manj (5890) in na Bledu npr. kar 3455.

\section{VPLIVI ČEZMEJNEGA ŠIRJENJA ONESNAŽENEGA ZRAKA}

V začetku 90. let, ko so predvsem ekonomski (manj okoljevarstveni) razlogi pripeljali do tehnoloških izboljšav pa tudi do zmanjševanja in opuščanja industrijske proizvodnje so se tudi zmanjšale količine idustrijskih emisij. Vendar pa tradicionalne onesnaževalce zraka (SO2, dim, prah) vse bolj zamenjujejo dušikovi in ogljikovi oksidi, ki so predvsem sestavine prometnih emisij. Slovenija je leta 1990 “proizvedla" 97,5 kg emisije SO2 na prebivalca (sredi 80. let celo $125 \mathrm{~kg} / \mathrm{preb}$.), do leta 1996 pa se je ta količina zmanjšale na $55 \mathrm{~kg} /$ preb. Pri dušikovih oksidih pa je bilo leta 1990 še 28,3 kg/preb emisij, v letu 1996 pa so te emisije narasle na 35,2 $\mathrm{kg} /$ preb. CO2, ki se uvršča med najpomembnejše toplogredne emisije, je Slovenija pred osmimi leti oddala v ozračje 6,8 ton/preb., leta 1996 pa že 7,6 ton/preb (MOP, Poročilo/96, 1998).

Če za lokalne vire emisij v Alpah lahko trdimo, da so v času najmočnejšega onesnaževanja povzročili le lokalno degradacijo okolja, omejeno na globoke doline, pa ugotavljamo, da na kakovost zraka v Alpah (ne le v reliefnih depresijah) vpliva tudi čezmejno širjenje škodljivih emisij. Med indikatorji za ta širši okoljevarstveni problem se najpogosteje uporabljajo podatki o kislih padavinah ter o mokrih in prašnih usedlinah. S posebnimi modelnimi izračuni strokovnjaki tudi ocenijo delež posameznih držav pri čezmejnem onesnaževanju zraka (MOP, Poročilo, 1998).

Znano je, da se velik del žveplovih in dušikovih spojin, ki izvirajo v naši državi, prenaša naprej preko državne meje, prav tako pa Slovenija prejme velik delež kislih usedlin iz drugih držav. V celoti gledano Slovenija v povprečju letno izvozi več dušikovih in žveplovih emisij kot jih prejme v obliki usedlin.

K skupnim usedlinam žvepla v Sloveniji prispevajo poleg domačih emisij tudi velike količine emisije iz sosednje Italije, sledijo pa še emisije iz Nemčije, Francije, Madžarske, Hrvaške, Češke in Poljske. Pri usedlinah oksidiranega dušika pa je delež iz domačih emisij manjši, več pa prispevajo viri v sosednjih državah, predvsem spet v Italiji (promet, TE), Nemčiji, Franciji in na Hrvaškem. Največ žveplovih emisij in dušikovih oksidov iz naše države "izvažamo" s čezmejnim širjenjem onesnaženih zračnih mas v Avstrijo, manj v Italijo, Madžarsko, Hrvaško oziroma na sredozemsko območje(MOP, Poročilo..1998). Slovenija ima z vidika čezmejnega prenašanja 
onesnaženega zraka neugodno lego. Iz srednje, zahodne pa tudi sredozemske Evrope, še posebno iz bližnje, močno industrializirane severne Italije, se onesnažene zračne gmote neovirano širijo do naših krajev, kjer jih orografske ovire ob alpsko-dinarskem stiku ustavijo. V orografsko okrepljenih padavinah, ki so med največjimi v Evropi, pa se iz ozračja izpirajo velike koločine žvepla (Radinja, 1988). Modelni izračun (po EMEP-u) kaže, da od 30300 ton celotnih usedlin žvepla v Sloveniji (v letu 1995) izvira 9700 ton (32\%) iz lastnih emisij, 20600 (68\%) pa iz emisij iz drugih držav. To torej pomeni, da je razmerje med avtohtonimi in alohtonimi viri depozitov žvepla $\mathrm{V}$ Sloveniji 1:3 (v prid uvoza) (MOP, Poročilo, 1998).

Prvi izmed posrednih indikatorjev širjenja onesnaženega zraka na večje razdalje so kisle padavine, njihova glavna povzročitelja sta $\mathrm{SO} 2$ in NOx. Na splošno velja za Slovenijo, da so padavine manj kisle (kisle so tiste padavine, katerih $\mathrm{pH}$ je 5,6 in manj) kot $\mathrm{v}$ nekaterih drugih evropskih državah s podobnim ali manjšim obsegom onesnaževanja ozračja. Radinja (1988) razlaga to pojav $\mathrm{z}$ nevtralizacijsko sposobnostjo pretežno karbonatne kamninske sestave, podnebnimi značilnostmi in izrazitimi letnimi časi, večjo humidnostjo, večjo hipsografijo, ki omogoča kroženje energije in snovi, pestrostjo pedološke odeje in pokrajinsko pestrostjo sploh. Analiza večletnih (Lešnjak, 1994) povprečij pH vrednosti, v letih do1980 do 1992 in novejših merjenj v letu 1996 ( HMZ,1997; MOP,1998,) kažejo, da se kislost padavin povečuje prav $\mathrm{v}$ krajih, kjer ni večjih avtohtonih onesnaževalcev zraka, npr. v Portorožu (vpliv širjenja onesnaženega zraka iz Italije) v Iskrbi (Kočevsko) in v dveh $\mathrm{v}$ alpskih krajih: na Bledu in na Jezerskem, šele nato jim sledijo kraji z večjimi količinami lastnih emisij: Ljubljana, Celje, Jesenice (HMZ, 1997).

Na obremenjevanje okolja pa, poleg kislih padavin, kažejo še podatki o usedlinah sulfatov in nitratov ter amonija. Sulfati so povezani z emisijam, ki nastajajo ob gorenju fosinih goriv, nitrati, povezani z emisijami NO, izvirajo pretežno iz prometa in termoelektrarn, emisije amonijaka pa pretežno iz kmetijstva.

Avstrijski strokovnjaki (Kovar, Puxbaum, 1993) so preučevali sestavo mokrih usedlin v ozračju Vzhodnih Alp. Analizirali so vse podatke, ki jih zbirajo merilne postaje v državah, ki so podpisnice Alpske konvencije in na območju Alpe-Jadran. S to raziskavo so namreč želeli oceniti ogroženost alpskega ekosistema, ki sam nima večjih avtohtonih virov onesnaževanja, so pa opazni vplivi čezmejnega širjenja onesnaženega zraka. Osnovna ugotovitev te študije je, da se onesnaženost Alp z Žveplovimi usedlinami postopoma zmanjšuje, na drugi strani pa količine nitratov celo polagoma naraščajo (promet!). To se ujema tudi s splošno oceno za Evropo, kjer se emisije žvepla postopno zmanjšujejo (tudi skladno s podpisom konvencije- akcijski načrt EU o zmanjšanju emisij SO2 za 35\% do leta 2000 glede na nivo leta 1985), vendar pa se povečujejo ali v najboljšem primeru stagnirajo količine dušikovij emisij, čeprav omenjeni mednarodni sporazumi napovedujejo tudi postopno zmanjševanje 
teh emisij (zmanjšanje emisij NOx za 30\% do leta 2000 glede na raven doseženo leta 1990).

Omenjene avstrijske študije (karta 1) kažejo, da so v Alpah najvišje koncentracije sulfatov in nitratov v usedlinah na severnih in južnih pobočjih. Žveplove usedline so v začetku tega desetletja dosegle najvišje vrednosti (med 3 in $4 \mathrm{~g} / \mathrm{m} 2$ ) prav na zahodni in južni meji Slovenije (v Italiji in na Hrvaškem), na območju slovenskih Alp pa med 2-3 g/m2. Na splošno so v Sloveniji v 15-letnem obdobju (1980-94) namerili največje količine sulfatnih usedlin na mestnih mernih mestih (povpečje 5-6 $\mathrm{g} / \mathrm{m} 2$ na leto), manj pa na podeželskih, kjer je bilo letno povprečje za omenjeno razdobje 2,6-3,2 gm2. Po najnovejših dostopnih podatkih (za leto 1996) se splošno zmanjšanje emisij žvepla pozna tudi na količinah usedlin. V mestnem okolju so se znižale na 1 do $2 \mathrm{~g} / \mathrm{m} 2$, na neurbanih mernih postajah pa se v povprečju te vrednosti približajo $1 \mathrm{~g} / \mathrm{m} 2$. Tudi tri "alpska" merna mesta imajo že nižje vrednosti žveplovih depozicij: Jesenice 1,7 g/m2, Jezersko 1,2, Bled 1,2 (HMZ,1997), kar pa je še vedno nad povprečjem za slovenska podeželska območja. Po oceni skandinavskih strokovnjakov so kritične obremenitve za ekosistem, kjer prevladuje gozd na pretežno karbonatni podlagi, med 0,8 in $3,2 \mathrm{~g} / \mathrm{m} 2$, na bolj občutljivih silikatnih pa že med 0,3 in $0,8 \mathrm{~g} / \mathrm{m} 2$ (Lešnjak, 1994). 
Slika 1: Letne depozicije $\mathrm{SO}_{4}-\mathrm{S}(1990)$

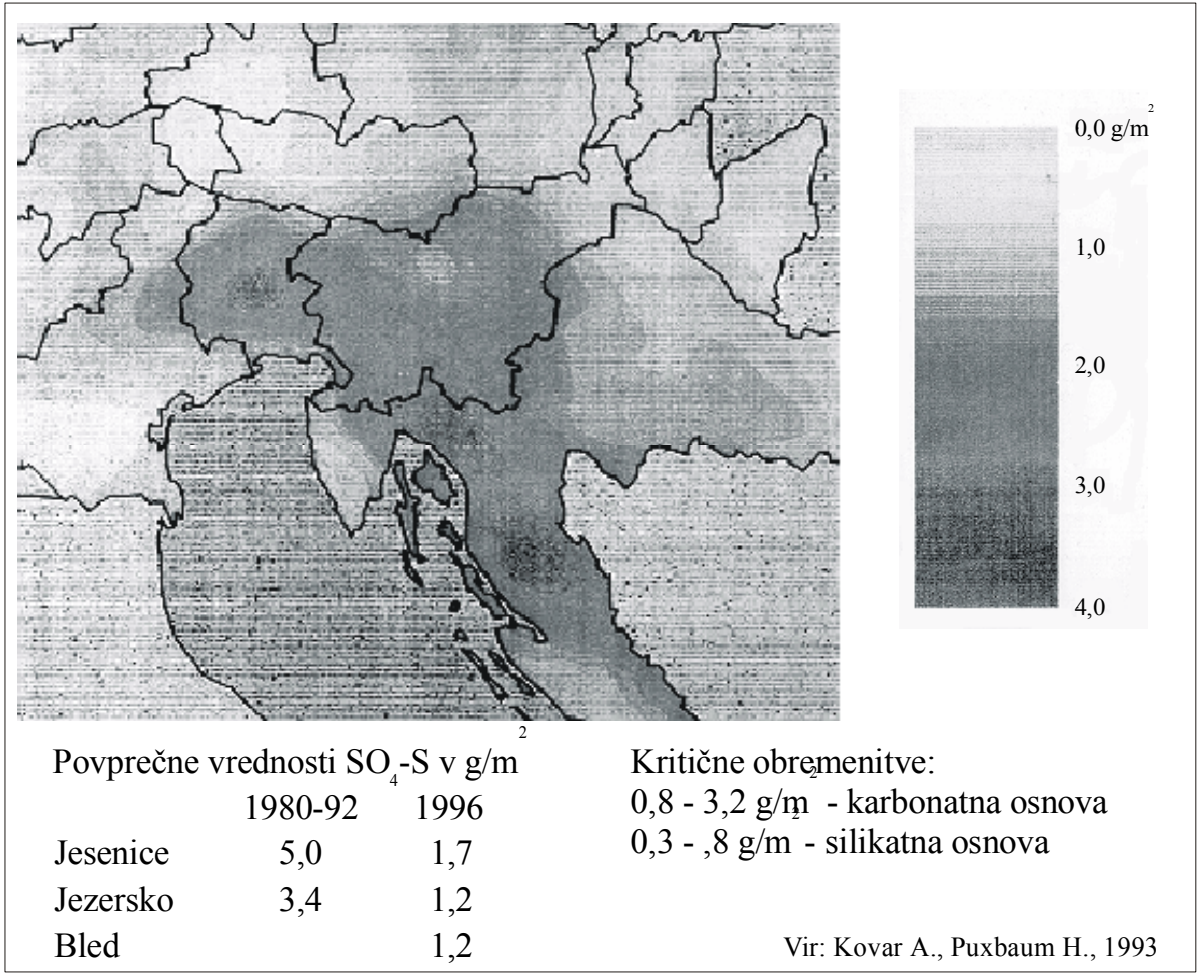

Pri usedlinah dušika ni občutnejših razlik med urbanimi in podeželskimi območji. V povprečju je bilo med leti 1980 in 1994 v Sloveniji 1,5 g/m2 teh usedlin na leto, v letu 1996 pa je so se te vrednosti med posameznimi mernimi postajami že gibale med 1,1 in $2,1 \mathrm{~g} / \mathrm{m} 2$ (HMZ, 1997). Primerjava s sosednjimi deželami (karta 2) kaže, da so tudi pri dušikovih usedlinah, podobno kot pri žveplovih, najvišje vrednosti izmerili leta 1990 zahodno in južno od naše države (SV Italija, S Hrvaška) in to med 1,5 in $2,0 \mathrm{~g} / \mathrm{m} 2$. Za slovenske Alpe so ocenili, da dušikove usedline ne presegajo $0,5 \mathrm{~g} / \mathrm{m} 2$ (Kovar..,1993). Podatki za leto 1996 pa kažejo že višje vrednosti. Med našimi alpskimi mernimi mesti so bile največje količine uedlin dušika na mernem mestu Jesenice 0,8 , na Jezerskem 0,5 in na Bledu $0,6 \mathrm{~g} / \mathrm{m} 2$ (HMZ, 1997). Za večino ekosistemov so kritične obremenitve med 0,3 in $1,5 \mathrm{~g} / \mathrm{m} 2$ dušikovih usedlin na leto. Pri ocenah splošnega obremenjevanja okolja pa je potrebno upoštevati sočasno delovanje obeh (žveplovih in dušikovih) onesnaževalcev in njun sinergijski učinek (Lešnjak, 1994). 
Slika 2: Letne depozicije NO4-N (1990)

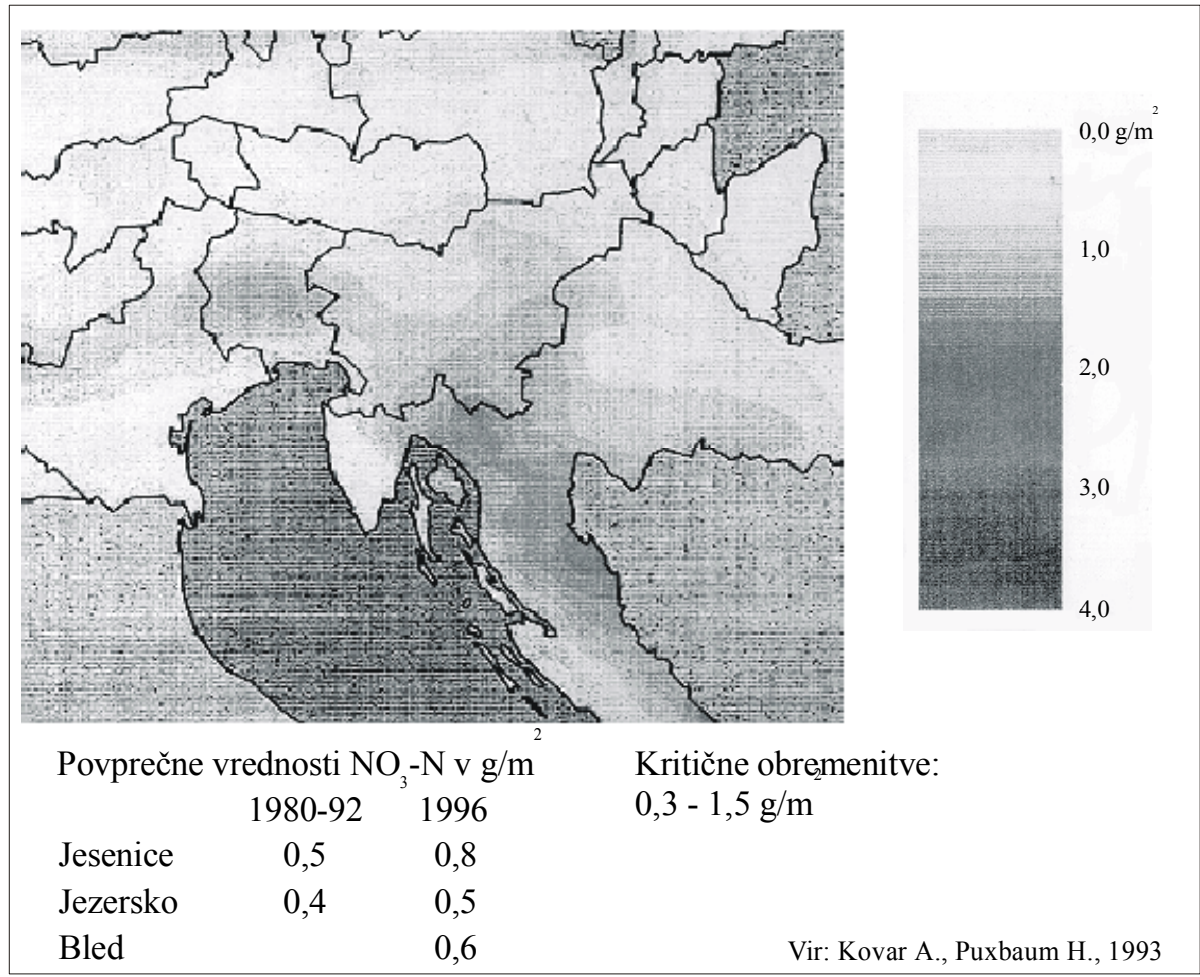

Ker v slovenskih Alpah ni večjih industrijskih niti komunalnih virov emisij, je zanimiva ocena avstrijskih strokovnjakov (Kovar, Puxbaum, 1994), da je le 8\% žveplovih usedlin $\mathrm{v}$ padavinah na območju Julijskih Alp oziroma v večjem delu Triglavskega narodnega parka slovenskega izvora. Največ, kar $40 \%$, prispevajo emisije iz Italije, 13\% iz Nemčije, 6\% iz Francija, 5\% iz Avstrije in 4\% iz Hrvaške. Ocena je narejena s simulacijo prenosa zračnih mas in z modelom širjenja žveplovih emisij na velike razdalje, podobno razmerje pa bi veljalo tudi za dušikove emisije. 
Skica 3: Izvor žveplovih usedlin v padavinah na območju TNP

\section{Izvor žveplovih usedlin v padavinah na območju TNP}

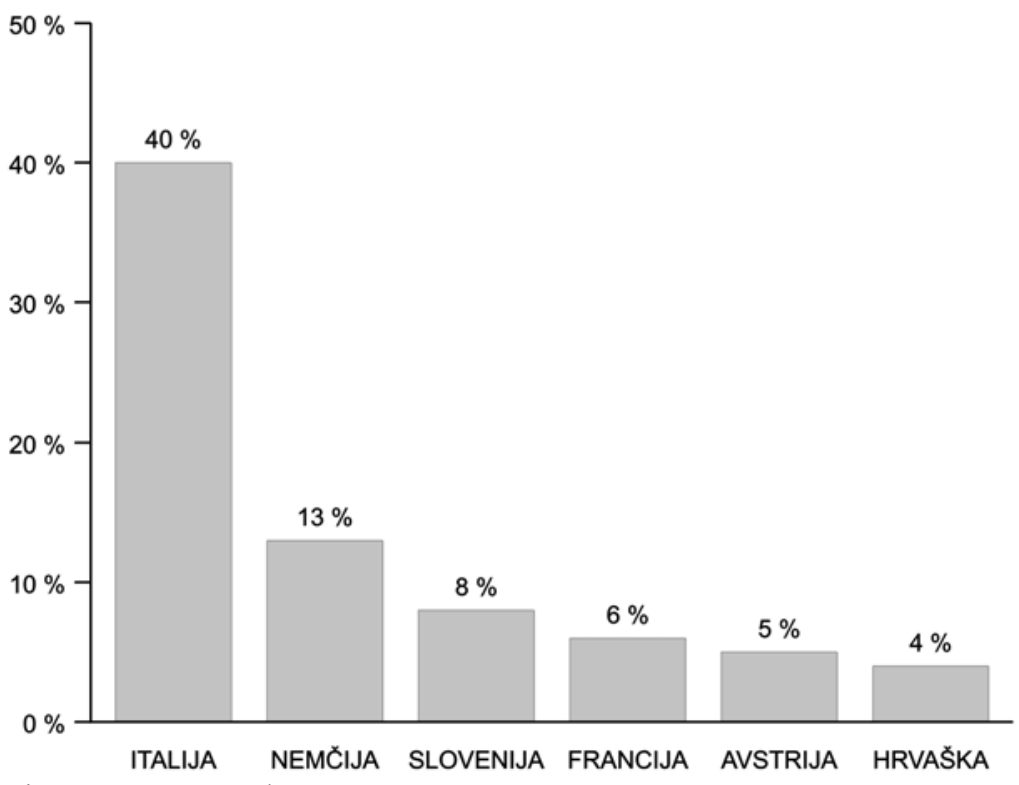

vir: Kovar A., Puxbaum H.,1994

\section{SKLEP}

$\mathrm{Na}$ splošno onesnaženost ozračja v Alpah, predvsem v dolinah in kotlinah, vplivajo reliefna razgibanost, $\mathrm{z}$ njo povezani specifični meteorološki pojavi (zatišnost, inverzije, pogoste megle) in s tem razmeroma slabe nevtralizacijske sposobnosti zraka. Zato že razmeroma majhne količine škodljivih emisij povzročajo negativne pokrajinske učinke. Tudi sama geografska lega našega alpskega ekosistema, ki ga obdajajo največji viri emisij (predvsem energetskih in industrijskih) $\mathrm{v}$ zahodni in srednji Evropi, neposredno vpliva na večjo onesnaženost zraka. S širjenjem emisij v zgornjih zračnih plasteh (vpliv visokih dimnikov!) na večje razdalje, tudi čez državne meje, se pojavljajo povišane imisije v okolju, kjer ni večjih avtohtonih virov emisij. 
V preteklih desetletjih, ko je bila onenaženost ozračja v Sloveniji največja, sta se med najbolj degradirane slovenske pokrajine uvrščali tudi dve alpski dolini: Zgornjesavska in Mežiška. Glavni industrijski viri in manjša naselja so sicer prispevali razmeroma majhne količine škodljivih emisij, vendar je bila njihova lega $\mathrm{v}$ ozkih in globokih dolinah z omejenimi samočistilnimi sposobnostmi z ekološkega vidika najmanj ugodna, pri čemer se je pokazalo veliko nesorazmerje med emisijami in imisijami.

Med indikatorje za čezmejno širjenje škodljivih emisij se najpogosteje uporabljajo podatki o kislih padavinah ter o mokrih in prašnih usedlinah. Analize kažejo, da so v Alpah najvišje koncentracije sulfatov in nitratov $v$ usedlinah na severnih in južnih pobočjih. Ker v slovenskih Alpah ni večjih industrijskih in komunalnih virov emisij, je zanimiva ocena avstrijskih strokovnjakov, da je le $8 \%$ žveplovih usedlin $v$ padavinah na območju Triglavskega narodnega parka slovenskega izvora. 


\section{LITERATURA:}

1. Gregorovič V. s sodelavci., 1984: Dinamika olova u sijenu i organizmu goveda u Mežiškoj dolini. Veterinarski glasnik. Beograd.

2. Hidrometeorološki zavod Slovenije RS, 1997: Onesnaženost zraka v Sloveniji v letu 1996. Ljubljana.

3. Inštitut za lesno in gozdno gospodarstvo, 1992: Poročilo o stanju gozdov. Naravni viri v Sloveniji, Ljubljana.

4. Kerin Ž., in D., 1978: Svinec v zemlji, rastlinah in vodah v Mežiški dolini. Zdravstveni vestnik, Ljubljana

5. Kovar A., Puxbaum H., 1993: Nasse Deposition im Ostalpenraum, Bayerisches Staatsministeriums fuer Landesentwicklung und Umweltfragen. München.

6. Kovar A., Puxbaum H., 1994: Wet Deposition Measurments in the Region of the Eastern Alps. Varstvo zraka- stanje in ukrepi za izboljšanje stanja v Sloveniji. ZTI. Ljubljana.

7. Lešnjak M., 1994: Meritve kakovosti padavin v Sloveniji. Varstvo zraka - stanje in ukrepi za izboljšanje stanja v Sloveniji. ZTI. Ljubljana.

8. Maček J., 1977: Dosedanje raziskave o vplivu industrijskih plinov in depozitov na vegetacijo v Sloveniji. Zelena knjiga o ogroženosti okolja v Sloveniji. Ljubljana.

9. Ministrstvo za okolje in prostor, 1998: Poročilo o stanju okolja 1996-osnutek. Ljubljana.

10. Premzl V., 1994: Alpska konvencija kot univerzalni instrument varovannja Alp. Okolje v Sloveniji-zbornik. Ljubljana. str. 207-213.

11. Radinja D., 1988: O tehnogenem kroženju žvepla v pokrajinskem okolju SR Slovenije in njegovi bilanci. Geografski vestnik. Ljubljana. str. 3-19.

12. Sušnik J., 1978: Delovanje onečiščenja okolja na ljudi v Mežiški dolini. Zdravstveni vestnik. Ljubljana.

13. Šolar M., 1972: Propadanje gozdov v Mežiški dolini. Tipkopis IGLG. Ljubljana.

14. Šolar M., 1978: Stanje gozdov v Mežiški dolini. Tipkopis IGLG. Ljubljana.

15. Šolar M., in ostali 1989: Propdanje gozdov v Sloveniji. Slovenija 88. SAZU. Ljubljana. str.309-324.

16. Špes M., 1998: Degradacija okolja kot dejavnik diferenciacije urbane pokrajine. Geographica Slovenica 30. Ljubljana.

17. The International Bank, 1994: Making Development Sustainable. From Concepts to Action. Washington. 


\title{
THE IMPACT OF LOCAL EMISSION SOURCES AND TRANSBORDER TRANSMISSION OF POLLUTED AIR ON THE ENVIRONMENTAL QUALITY OF THE ALPINE ECOSYSTEM
}

\begin{abstract}
Summary
When discussing the general air pollution in the Alps, it should be primarily emphasized that the Alpine ecosystems have rather poor neutralizing air capacities due to the landforms and the resultant specific meteorological phenomena (calms, inversions, frequent fogs). This is most evidently manifested in Alpine and subalpine valleys and basins where the relatively small quantities of harmful emissions already cause intense negative landscape effects. The second environmental protection characteristic of the Alps is represented by their geographical position. They are located amidst the greatest emission sources (especially the energy-related and industrial sources) in West and Central Europe. Due to the transmission of these emissions in the upper air layers (the impact of high chimneys) to larger distances and even beyond the state borders, the increased concentrations of pollutants occur in the environment without any greater autochtonous emission sources.

In the past decades, when the air pollution in Slovenia was the heaviest, two Alpine valleys ranked among the most degraded Slovenian landscapes: the Zgornjesavska dolina and the Mežiška dolina. Although the main industrial sources and smaller settlements contributed rather small quantities of harmful emissions, their locations in the narrow and deep valleys of only limited self-purifying capacities from the ecological point of view were least favourable, which resulted in great disparities between the emissions and the concentrations of pollutants.

The quality of air in the Alps (not only in the landforms' depressions) is also influenced by the transborder transmission of harmful emissions. Of the indicators of this broader environmental protection problem, the data on acid precipitation and moist and dust deposits are most often used. Analyses show that the highest concentrations of sulphates and nitrates in the Alps occur in the deposits of precipitation falling on the northern and southern slopes. Since there are no great industrial or communal sources of emissions the judgement of two Austrian experts (Kovar, Puxbaum) is indicative, namely that only $8 \%$ of sulphur deposits of the precipitation falling in the area of the Triglav National Park originate in Slovenia. The greatest percentage, as much as $40 \%$, is due to the emissions from Italy, $13 \%$ come from Germany, $5 \%$ from Austria, $4 \%$ from Croatia, etc.
\end{abstract}

